\title{
Minando ouro: utilizando o Nachlaß e as preleções de Kant como fonte para sua filosofia política
}

\author{
Frederick RaUscher \\ Professor da State University Michigan
}

\section{I: A filosofia política ${ }^{1}$ de Kant}

$\mathrm{Na}$ história da humanidade, o ouro tem sido símbolo de poder, riqueza, prestígio e beleza. Aqueles que o têm, cuidam dele. Aqueles que não o possuem, lutam por ele. É muito difícil de ser obtido: deve-se encontrar uma fonte provável, e para se chegar até ela uma mina deve ser cavada, o minério extraído da terra e o ouro purificado pela separação do minério bruto. A tarefa é difícil, mas a recompensa é enorme.

Gostaria de fazer do ouro não somente um símbolo de poder, riqueza, prestígio e beleza, mas também um símbolo das melhores passagens nos escritos inéditos de Kant sobre filosofia política. Temos montanhas de papéis para pesquisar, devemos escavar as seleções mais valiosas, e precisamos avaliá-las para encontrar os argumentos puros escondidos entre a escória. Mas quando se encontram estas pepitas, elas podem valer o esforço.

O trabalho inédito de Kant sobre filosofia política que sobreviveu se apresenta em três tipos, como três montanhas que escondem ouro em sua massa. Cada uma destas fontes tem um uso diferente e diferentes restrições em seus valores. Os três tipos de fontes são a) preleções b) as notas de Kant para as preleções e outras reflexões em geral c) rascunhos para livros e ensaios espe-

1. Na apresentação deste trabalho feita em Agosto de 2009 na Universidade de São Paulo, quando indagado sobre o uso da expressão "political philosophy", o autor explicou que ela é usada aqui num sentido amplo, que abarca o que chamaríamos separadamente de filosofia do direito e filosofia política. (N. do T.) 
cíficos. Como graus diferentes do minério do qual o ouro deve ser extraído, estas diferentes fontes precisam ser avaliadas pelo seu valor e pelas ideias puras que elas contém.

Como um exemplo da utilidade destas fontes inéditas, focarei no tópico da punição. Mostrarei como algumas delas podem lançar luzes sobre a visão de Kant publicada acerca da punição. Também mostrarei como este tópico se relaciona com a idéia de contrato social de um modo que ilumina tanto a idéia de contrato, como a justificativa da punição. O resultado, eu espero, mostrará como o ouro extraído destas fontes vale tanto quanto o ouro que Kant incluiu em seus livros.

Primeiramente, farei uma retomada dos três tipos de fontes.

\section{II: O material}

As Preleções

As preleções de Kant eram extremamente populares, particularmente suas preleções anuais sobre Antropologia e Geografia Física, que ele considerava como material introdutório. Estas preleções eram transcritas pelos estudantes, que em geral contratavam copistas para fazer cópias das notas da preleção a fim de vendê-las a outros estudantes, naquele ou nos próximos semestres. Vários destes escritos póstumos (Nachschriften) sobreviveram e estão publicados na Kants Gesammelte Schriften, volumes 24-29.2

Naturrecht $^{3}$ (direito natural, ou, de um modo mais amplo, filosofia política) aparentemente não era ensinado com muita frequência. Os registros que sobreviveram indicam que Kant ofereceu o curso somente uma dúzia de vezes entre 1767-1788, e não

2. Kant, I. Kants Gesammelte Schriften. Herausgegeben von der Königlich Preussischen Akademie der Wissenschaft. 29 Vols. Berlin: Walter de Gruyter, 1902 e ss. Somente em 2009 o conjunto ficou completo com a publicação do volume 26, Preleções sobre Geografia Física, editado por Werner Stark. [Esta edição é comumente conhecida pelo nome de Edição da Academia, e será assim referida no texto daqui em diante. (N.do.T)]

3. Traduz-se por direito natural. (N. do. T)

12 
mais depois desta data. ${ }^{4}$ De acordo com as regras da universidade, quando lecionava, Kant era obrigado a escolher e seguir um manual. Ele nunca se utilizou de nenhum de seus próprios livros para este propósito, mas sempre selecionava textos tradicionais tais como Metaphysica de Alexander Baumgarten. Para o curso Naturrecht ele utilizou o Jus Naturaes de Gottfried Achenwall, publicado em 1763. O livro de Achenwall era uma revisão de um texto anterior muito popular, Elementa Juris Naturae que ele havia co-escrito com Stephan Pütter em 1750.5 Ambos eram professores na Universidade de Göttingen, Pütter na faculdade de direito e Achenwall na faculdade de filosofia, e haviam se encontrado 10 anos antes quando eram estudantes em Halle. ${ }^{6}$

Sabe-se que apenas dois conjuntos das transcrições das preleções de Kant sobre filosofia política sobreviveram. Um deles, anotado por Friedrich von Gentz, foi perdido bem antes de poder ser publicado. ${ }^{7} \mathrm{O}$ outro, anotado por Gottlieb Feyerabend,

4. Informações sobre as preleções de Kant estão disponíveis em Arnoldt, E. Gesammelte Schriften. Band V Teil II. Berlin: Verlag Bruno Cassirer, 1909. Há também dois websites: http://web.uni-marburg.de/kant/, a fonte online do Arquivo Kant da Universidade de Marburg, e www.manchester.edu/ kant, um site criado por Steve Naragon dedicado a "Kant na Sala de Aula".

5. Achenwall, G., Jus Naturae. 5a. edição. Gottingen, 1763. A primeira edição é Achenvall, G.; Pütter, S. Elementa Juris Naturae, Gottingen, 1750. Esta edição foi traduzida para o alemão por Jan Schröder como Achenvall, G.; Pütter, S. Anfangsgründe des Naturrechts. Trad. por Jan Schröder. Frankfurt: Insel Verlag, 1995; a edição de Achenwall que foi usada por Kant permanece sem tradução.

6. Começando com a terceira seção de seu livro, Achenwall trabalhou sozinho na atualização do texto já que os interesses de Pütter mudaram da filosofia política e teoria legal para o direito positivo. Dado que Pütter contribuiu apenas com uma fração do material da edição original, as edições posteriores do livro levavam somente o nome de Achenwall e era já naquela época, e continua sendo hoje, considerada como sendo um trabalho de Achenwall.

7. Gentz (1763-1832) matriculou-se na Universidade de Königsberg em 26 de abril de 1784. Seu único Nachschrift é o Naturrecht. É mencionado em Stargardt, KAT 234 (uma antiga casa de Berlin que trabalha com livros autografados e manuscritos antigos), como estando em posse particular, e do qual atualmente não se tem notícia. Informações sobre o estado destes manuscritos estão disponíveis no website de Margburg mencionado na nota 
foi publicado no volume 27.2.2 da Academia. Nada se sabe de Feyerabend além da sua matrícula na universidade (6 de maio de 1783) e seu nome escrito nas notas. O manuscrito original se encontra atualmente na biblioteca central de Gdansk, Polônia. Uma reprodução do manuscrito está disponível nos Arquivos Kant de Marburg.

O primeiro quarto das preleções não se refere ao texto de Achenwall, funcionando antes como uma introdução ao tópico. Este material é talvez o mais claro sumário das fundações de sua filosofia prática em geral, e fornece um conjunto detalhado das distinções entre seus componentes, filosofia política (Recht) e virtude (Tugend); estas discussões são extremamente importantes dada sua datação relativa a Fundamentação e a segunda Crítica, que geralmente são consideradas como fundamentando apenas a virtude. $\mathrm{O}$ restante das notas da preleção segue relativamente de perto o texto de Achenwall. Com frequência, Kant cita frases do manual em latim antes de fazer seu próprio comentário. As reflexões de Kant sobre direito internacional na parte final do curso ocupam apenas algumas páginas, e diferentemente de partes anteriores do manuscrito, ele dispensa a discussão e fornece uma lista de princípios para o direito internacional e para o direito de guerra; considero isto como uma evidência de que ele estava ficando sem tempo para tratar de todos os tópicos que ele queria tratar em suas preleções.

Quando se utilizam as preleções como fonte, é preciso tomar cuidado. Primeiramente, o estudante que tomou as notas deve ser acreditado como tendo registrado corretamente os pensamentos de Kant. Em segundo lugar, o copista deve ser acreditado como tendo copiado de modo diligente frases e palavras do manuscrito original. Por último, o editor deve ser acreditado como tento percebido todos os problemas e variações importantes no manuscrito.

acima e também em Stark, W. Nachforschungen zu Briefen und Handschriften Immanuel Kants. Berlin: Akademie Verlag, 1993. 


\section{O Nachla}

Kant não redigiu anotações específicas para suas preleções, baseando-se antes nas notas que escreveu nos manuais. Um de seus alunos assim descreve suas preleções:

Suas preleções eram completamente livres. Em muitas aulas ele nem se servia de um caderno, ao contrário, ele tinha algumas anotações nas margens de seus manuais para servir como fio condutor. Em geral ele trazia consigo apenas um pequeno pedaço de papel, no qual ele tinha registrado seus pensamentos numa escrita diminuta e sucinta. (Reinhold Jachmann) ${ }^{8}$

É sabido mesmo que Kant, algumas vezes, mandava imprimir os manuais que utilizava com páginas em branco entre cada página impressa para ter espaço suficiente para suas notas. (Não é este o caso do livro de Achenwall). Com o passar dos anos, os manuais de Kant acumulavam camadas de notas de períodos diferentes. O mais talentoso editor da Edição da Academia, Erich Adickes, foi capaz de datar estas notas usando a cor da tinta e outros fatores para distinguir aquelas que provinham de diferentes períodos do desenvolvimento de Kant.

A cópia de Kant do texto de Achenwall utilizado nas suas preleções foi perdida na Segunda Guerra Mundial, mas nesta épo$\mathrm{ca}$ as transcrições de suas notas feitas nas margens e nas folhas em branco intercaladas já haviam sido publicadas no Volume 19 da Academia. As Reflexôes sobre Filosofia do Direito consistem em material do próprio manual de Kant, mais um pequeno número de folhas soltas (Lose Blätter) identificadas pelos editores da Academia dedicadas primordialmente aos mesmos tópicos. Estas reflexões revelam o grande e duradouro interesse de Kant pelo

8. Citado da coletânea Malter, R (ed.). Immanuel Kant in Rede und Gespräch. Hamburg: Felix Meiner, 1990, p. 217. [As traduções foram feitas todas a partir do texto em inglês. Foram conferidos os originais a fim de guiar nossa tradução. A escolha de traduzir tudo a partir do inglês visou manter a coesão do texto. Quando os textos já haviam sido anteriormente traduzidos para o português, optou-se por utilizar as traduções existentes. (N.do T.)] 
pensamento político, e também sua própria evolução. As notas mais antigas datam de aproximadamente 1766 , logo após a transformação que o próprio Kant descreveu acerca de si mesmo em reação as obras de Rousseau. As últimas notas incluem algumas que datam de 1797, isto é, depois da publicação da Doutrina do Direito.

Nós podemos supor que as notas escritas na sua cópia do livro de Achenwall eram usadas por Kant em seus cursos. Em alguns casos elas são meros sumários do texto de Achenwall. Em outros, elas poderiam ser argumentos fornecidos por terceiros em defesa dos mesmos pontos. É certo que muitas delas mostram a visão de Kant. Mas deve-se ser cuidadoso ao atribuir qualquer argumento específico a Kant. Se a reflexão não se parece com algo que ele diz em outros lugares, então é sábio não prestar atenção a ela.

\section{Os Rascunhos}

Poucos manuscritos de livros e rascunhos de ensaios (Vorarbeiten) de Kant para obras importantes como a Fundamentação sobreviveram, porém mais de duzentas páginas de rascunhos da Metafísica dos Costumes estão disponíveis. Estes rascunhos fornecem um tratamento extenso, de várias páginas, acerca de tópicos específicos, conforme Kant registra várias versões propostas de argumentos e discussões de seus próprios trabalhos. Este material para a Metafísica dos Costumes e outros materiais relacionados estão reunidos no volume $23 \mathrm{da}$ Academia. (Rascunhos similares para a Crítica da Razão Pura estão integrados às Reflexóes nos Volumes 17 e 18)

A doutrina do direito em particular demandou muito esforço de Kant. Mais de 63 páginas de rascunhos lidam exclusivamente com o tópico da propriedade. Dado que o contrato social está intimamente ligado à proteção da propriedade de cada um - e dado que uma característica única do contrato social de Kant é a reivindicação de que a propriedade enquanto tal só é possível com base em um contrato social - este material lança muita luz no pensamento político de Kant. Outro material importante inclui as introduções, tanto para a Metafísica dos Costumes como um todo, 
como para a Doutrina do Direito e a Doutrina da Virtude em particular - que estabelece os parâmetros básicos da filosofia política em sua relação com a ética, mas a distingue da ética propriamente dita (virtude), rascunhos sobre Direito Público que concernem à soberania, à punição, à desobediência civil e outros tópicos.

O volume 23 da Academia também contém rascunhos de alguns dos ensaios políticos de Kant. O ensaio conhecido como Teoria e Prática ${ }^{9}$ contém um sumário da filosofia política de Kant que enfatiza a liberdade, a igualdade e a independência, e também discute o progresso internacional; Para a Paz Perpétua ${ }^{10}$ fornece o argumento de Kant a favor de uma federação de Estados; há também um fragmento anotado que parece ser da cópia enviada ao impressor mostrando as mudanças finais no manuscrito (pp. 17592); Está a raça bumana progredindo constantemente? ${ }^{11}$ centra-se na história, mas enfatiza a natureza política do progresso.

Utilizar estes rascunhos ajuda a traçar a gênese dos trabalhos publicados de Kant. No caso da Crítica da Razão Pura, uma década de trabalho - a famosa "década silenciosa" - foi preservada e fornece uma boa quantidade de informações sobre os vários argumentos nos quais Kant trabalhou, as diversas estruturas do livro que ele considerou, e, é claro, os tópicos chaves do livro conforme ele se desenvolveu. ${ }^{12}$

Os perigos de se apoiar muito sobre os rascunhos é que, certamente, Kant decidiu não levar a público precisamente aquele argumento, fraseado ou tópico contido no rascunho, mas não

9. Kant, I. Kants Gesammelte Schriften. Herausgegeben von der Königlich Preussischen Akademie der Wissenschaft. Vol. 23, pp. 127-43.

10. Kant, I. Kants Gesammelte Schriften. Herausgegeben von der Königlich Preussischen Akademie der Wissenschaft. Vol. 23, pp. 155-75.

11. Kant, I. Kants Gesammelte Schriften. Herausgegeben von der Königlich Preussischen Akademie der Wissenschaft. Vol. 23, pp. 455-62.

12. Como resultado, eu acredito que a organização da versão final publicada não deve ser tomada tão a sério, já que ela reflete apenas uma tentativa de Kant de juntar as várias partes do todo em desenvolvimento. Diz-se que o Chanceler Alemão Otto Von Bismark teria dito que "leis são como salsichas, é melhor não vê-las sendo feitas". Acredito que talvez pudéssemos adicionar os livros de filosofia a esta lista. 
na versão publicada. Entretanto, pode haver muitas razões pelas quais Kant não levou a público este material. Trabalhando nossas idéias, geralmente tentamos diferentes modos de expressar a mesma coisa, e quando definimos um modo para a publicação, nem sempre rejeitamos os modos de expressão anteriores. Além disso, com o tempo, costumamos mudar de opinião sobre os argumentos e idéias que publicamos. Ao traçar o desenvolvimento do pensamento, fontes publicadas e inéditas podem ambas revelar argumentos que podem ter sido atraentes em algum momento anterior, tendo sido, talvez, rejeitados. Não se pode excluir a possibilidade de que, tendo relido estas notas, Kant poderia ter decidido publicar partes delas.

Com todas estas fontes inéditas - notas de alunos, reflexões e rascunhos - nós precisamos lembrar que estamos abordando este material nós mesmos enquanto filósofos, e não apenas como historiadores. Enquanto historiadores da filosofia, nós queremos preservar o registro dos pensamentos de Kant e torná-lo disponível a outros (é por isto que embarcamos em projetos de tradução). Como historiadores da filosofia, nós queremos estar capacitados para entender e avaliar as afirmações feitas por Kant. Se decidimos, em nosso juízo, que uma idéia ou argumento não publicado é superior a um publicado, nós deveríamos incorporá-lo em nossa avaliação sobre Kant. Deveríamos, ao menos, nos sentir livres para utilizar o material inédito a fim de iluminar o material publicado, talvez fazendo conexões que Kant não faz explicitamente neste último. Para retornar a metáfora do ouro, nós queremos refinar o minério que encontramos para o transformas em um ouro utilizável. Agora proponho uma tentativa de mostrar este processo.

\section{III: Punição e o Contrato Social}

Em meu exemplo, examino uma afirmação específica que Kant faz em seus argumentos que foram publicados sobre a justificativa da punição, em particular da pena de morte. O contexto da sua afirmação é um argumento contra a pena de morte dado pelo jurista italiano Cesare Beccaria, que advogava em favor de uma reforma penal. A resposta de Kant a Beccaria invoca a idéia de um contrato social. Examinando esta passagem à luz de algumas 
fontes não publicadas, mostrarei o quanto elas aprofundam nossa compreensão das asserções de Kant tanto sobre a punição quanto sobre o contrato social.

O livro de Beccaria, Dos Delitos e Das Penas (1764) ${ }^{13}$ adota uma estrutura do contrato social. Os indivíduos se combinam em uma sociedade para o seu bem individual próprio, sendo que as leis "deveriam ser pactos entre homens livres". ${ }^{14}$ Para obter a felicidade que eles podem ter, os indivíduos concordam em sacrificar parte da sua liberdade para a ordem, e assim "poderem gozar o restante com segurança e tranquilidade". ${ }^{15} \mathrm{~A}$ liberdade é vista mais como um meio para a felicidade individual do que como tendo valor em si mesma. Todos concordam em abrir mão de uma parte de sua liberdade - presumivelmente a parte correspondente a cada um, embora Beccaria não seja específico - e o poder correspondente a essa liberdade constitui o poder do soberano. O soberano, portanto, goza de um repositório de liberdade que poderia ser utilizada para obter a felicidade, mas que os indivíduos voluntariamente sacrificaram para maximizar a sua felicidade realmente alcançável.

As punições estão incluídas no contrato social do seguinte modo. "Para prevenir o espírito despótico de cada homem de resubmergir as leis da sociedade no caos antigo", motivos sensíveis são fixados: "estes motivos sensíveis são as penas estabelecidas contra os infratores da lei” ${ }^{16}$ Mas estas punições estão sujeitas às limitações originais de um contrato, já que cada cidadão cede voluntariamente "a mínima porção possível, apenas a que baste para induzir os outros a defendê-lo". ${ }^{17} \mathrm{O}$ direito do governo de punir é, portanto, limitado ao tanto de liberdade contida naquele conjunto das menores quantidades possíveis consistentes com a manutenção da ordem na sociedade sob leis.

13. Beccaria, C. Dos delitos e das penas. $3^{\mathrm{a}}$ ed. Trad. Lucia Guidicini e Alessandro Berti Contessa. São Paulo: Martins Fontes, 2005.

14. Beccaria, C. Dos delitos e das penas, p. 39.

15. Idem, p. 41.

16. Idem,ibidem.

17. Idem, p. 43. 
Ao determinar o conteúdo da "mínima porção possível" de liberdade a ser cedida pelos indivíduos, deve-se levar em conta o que é racional para uma pessoa ceder ${ }^{18}$. No caso específico da pena capital, Beccaria argumenta que é absurdo acreditar que os indivíduos voluntariamente cederiam suas próprias vidas ao soberano:

Mas quem será o homem que queira deixar a outro o arbítrio de matá-lo? Como pode haver, no menor sacrifício da liberdade de cada um, o do bem maior de todos, a vida? E, se assim fosse, como se coaduna tal princípio com o do outro, de que o homem não pode matar-se? Não deveria ele ter esse direito se pôde atribuí-lo a outrem ou à sociedade inteira? ${ }^{19}$

Dois pontos são sustentados nesta passagem. Primeiro, que o direito de tirar a própria vida não pode racionalmente ser dado ao soberano por um indivíduo que entra em sociedade para maximizar sua felicidade possível, porque a vida mesma é precondição para toda felicidade. Alguns podem replicar que a pena capital pode ser racionalmente incluída num contrato social porque ela é a dissuasão mais efetiva contra o crime; isto Beccaria contraargumenta que uma perda permanente de liberdade pela servidão involuntária durante toda a vida seria um obstáculo muito mais eficiente (Beccaria, 68;99). O segundo ponto desta passagem é que, se se argumentasse que é racional dar o poder sobre a vida de alguém ao soberano, ainda assim seria impossível fazê-lo, pois ninguém possui o direito a ter poder sobre sua própria vida, dada a proibição moral contra o suicídio.

18. Beccaria se utiliza deste embasamente para argumentar de modo geral contra as punições excessivas. Ele sustenta que o caráter extremamente severo de algumas punições vai além do tanto requerido para "ao bem comum e ao próprio fim de impedir os delitos e o objetivo de desencorajar crimes" (Idem, p. 45) e é por isto injusto. As punições devem ser direcionadas de modo a prevenir que o criminoso cometa outros crimes. As punições deveriam ser "selecionadas de tal modo a causar a mais eficaz e duradoura impressão nos espíritos dos homens com o mínimo de tormento ao corpo do condenado". Idem, p. 31. Este é um ponto distinto de seu argumento sobre a pena capital e não será tratado aqui.

19. Idem, p. 94. 
Na "Doutrina do Direito" (parte da Metafísica dos Costumes) Kant menciona diretamente Beccaria na seguinte passagem:

O marquês Beccaria, na base do sentimentalismo de um humanitarismo afetado (compassibilitas), estabeleceu a sua tese da ilicitude de toda a pena de morte: dado que ela não poderia estar contida no contrato civil, originário; pois que, neste caso, cada membro do povo haveria que ter consentido em perder a sua vida se matasse qualquer outro (membro do povo); mas este consentimento é impossível, porque ninguém pode dispor da sua vida. Tudo sofística e cavilação. ${ }^{20}$

A primeira vista parece que o argumento de Beccaria não deveria ser rejeitado tão rápido por Kant. Ele mesmo concorda que ninguém tem o direito de dispor de sua própria vida. ${ }^{21}$ Também se supõe que para Kant o contrato social é uma questão da vontade. Se a pena capital fosse parte do contrato social, então não teria Kant que concordar que ninguém concordaria por sua própria vontade com aquele contrato, porque isto significaria desejar a possibilidade da sua própria morte? Kant avança ainda mais ao notar que toda punição é definida como um dano à pessoa feito contra a vontade daquela pessoa. ("quando a alguém acontece aquilo que quer não existe punição, e é impossível querer ser

20. Kant, I. Metafísica dos costumes. In: Kants gesammelte Schriften. Herausgegeben von der Königlich Preussischen Akademie der Wissenschaft. Vol. 6, pp. 334-5. Referências às obras de Kant serão dadas pelo volume e página da Edição da Academia. Estas páginas são dadas na margem das traduções para o inglês. Para as traduções em inglês, eu utilizo: Kant, I. Practical Philosophy. Trad. de Mary Gregor. New York: Cambridge University Press, 1996. As traduções do Nachlaß e das Preleções de Kant são minhas. [Utilizaremos as traduções em português para as obras citadas pelo autor que tiverem tradução. Nos demais casos, traduziremos diretamente do inglês, colocando a versão inglesa em nota de rodapé, por já se tratar de uma tradução feita pelo autor. Cf. Nota 8. Para as Reflexôes de número 7914, 7917 e 8037, as traduções foram feitas diretamente do alemão (a tradução completa consta neste volume dos Cadernos de Filosofia Alemã). Kant. I. Metafísica dos Costumes. Trad. de José Lamego. Lisboa: Fundação Calouste Gulbenkian, 2005, p. 214-215]

21. Kant, I. Metafísica dos costumes. In: Kants gesammelte Schriften. Herausgegeben von der Königlich Preussischen Akademie der Wissenschaft. Vol. 6, p 422. 
punido"22). Como pode, então, qualquer punição, e mais ainda a pena capital, ser incluída num contrato social que supostamente cada cidadão quer?

Kant inclui o argumento de Beccaria nas suas próprias notas à margem de sua cópia do texto de Achenwall:

Se o direito à pena capital devesse ser considerado como proveniente de um pacto do povo inteiro com cada indivíduo, então se diria, mais precisamente, que não se poderia aplicar a pena de morte. Pois, se a nação não fizesse isto, então ela daria aos indivíduos, por assim dizer, a autorização para tirar suas próprias vidas (isto é, não os impediria), o que ninguém está autorizado a fazer. ${ }^{23}$

E na transcrição do curso de Kant feita por Feyerabend, ele apresenta o argumento de Beccaria do seguinte modo:

Beccaria diz: todas as leis devem ser vistas como se elas proviessem da vontade unânime do povo. Eles poderiam acarretar punições, impostos, etc, a si mesmas, mas eles não tem autoridade para dispor \{disponiren\} sobre suas vidas. De acordo com estes mesmos princípios, não se poderia consentir na prisão perpétua. Porque é claro que não se pode dispor \{disponiren\}de sua própria liberdade. $\mathrm{O}$ açoite jamais poderia ser aprovado porque ele desonra a humanidade..$^{24}$

Kant, é claro, rejeita estes argumentos como "sofística e cavilação". Para fazer isto, ele tem que mostrar que o modo como os indivíduos querem o contrato social é distinto do modo como estes mesmos desejam o ato específico da punição sob o contrato social. Eis como ele apresenta o argumento na versão publicada da Doutrina do Direito:

Dizer: quero ser punido se matar alguém não significa senão dizer que me submeto juntamente com todos os demais às leis penais.

22. Idem, p. 335.

23. Kant, I. Kants Gesammelte Schriften. Herausgegeben von der Königlich Preussischen Akademie der Wissenschaft. Vol. 19, p. 553.

24. Kant, I. Kants Gesammelte Schriften. Herausgegeben von der Königlich Preussischen Akademie der Wissenschaft. Vol. 27, pp. 1391. 
Eu, enquanto colegislador que dita a lei penal, não posso ser a mesma pessoa que, enquando súbdito, é punida de acordo com a lei; porque, enquanto tal, quer dizer, enquanto criminoso, não posso ter um voto na legislação (o legislador é sagrado). Portanto, quanto formulo uma leia penal contra mim, como criminoso, é a razão pura juridicamente legisladora em mim (homo noumenon ) que me submete à lei penal, como capaz de cometer crimes, por conseguinte, como uma outra pessoa (homo phaenomenon) em conjunto com todas as outras na associação civil. Por outras palavras: não é o povo (cada indivíduo em si mesmo) que dita a pena de morte, mas o tribunal (a justiça pública), alguém distinto do criminoso, portanto, e no contrato social não está de modo algum contida a promessa de permitir ser punido, dispondo, assim, de si próprio e da própria vida..$^{25}$

Em suma, o argumento de Kant diz que Beccaria confundiu razão com vontade. É verdade que ninguém pode querer ser punido pois ninguém pode ter um desejo de ser inflingido com o sofrimento ou perda da liberdade acarretada pela punição. Contudo, ao mesmo tempo, enquanto ser racional, é se capaz de endossar a punição. Neste segundo sentido, pode-se desejar a punição.

Como podem estes dois sentidos de vontade operar simultaneamente sem contradição? Kant emprega a linguagem do idealismo transcendental quando identifica homo noumenon e homo phaenomenon, e quando afirma que são pessoas distintas. Por "homo noumenon" Kant não quer dizer aqui a pessoa como uma coisa em si mesma, considerada idependemente da pessoa empírica de carne e osso que comete o crime. ${ }^{26}$ Antes, Kant identifica homo noumenon com a razão pura em mim. Razão pura é a fonte

25. Kant, I. Metafísica dos costumes. In: Kants gesammelte Schriften. Herausgegeben von der Königlich Preussischen Akademie der Wissenschaft. Vol. 6, p 335. Kant, I. Metafísica dos Costumes, p. 215

26. Samuel Fleischacker nota, de modo acertado, os problemas que resultam quando alguns comentadores tentam interpretrar esta passagem utilizando um "duplo si”. Em sua própria interpretação, Fleischacker não enfatiza, como eu o faço, a distinção entre razão e vontade. Fleischacker, S.”Kant's Theory of Punishment". In: Williams, H. L. Essays on Kant's Political Philosophy. Chicago: University of Chicago Press, 1992, pp. 191-212, especialmente pp. 195-8. 
do princípio do direito e, em última instância, de todos os deveres legais a priori. Isto inclui o direito de entrar em um contrato social e a autorização da coerção para manter a liberdade. A razão pura pede que eu endosse a prática da punição como exigência para sustentar o princípio do direito. Isto pode incluir a pena capital. Ao mesmo tempo, tenho uma vontade que escolhe endossar desejos particulares, que nós podemos chamar de vontade voluntária. Naturalmente, esta vontade voluntária não escolhe e não pode escolher (sem contradição) negar a si mesma com sua morte, e assim não endossa a pena capital. Esta vontade voluntária também deseja evitar qualquer perda de felicidade e liberdade.

Para que este argumento contra Beccaria funcione, a concepção de Kant do contrato social precisa ser tal que associe o endosso do contrato social pela razão e não pela vontade voluntária. Em outras palavras, deve haver um sentido no qual o endosso do contrato social não é uma opção para o invíduo, para ele escolher ou abster-se de escolher. $\mathrm{O}$ contrato social deve ser válido independentemente da vontade voluntária, o que significa independentemente das razões que normalmente alguém daria para escolher alguma coisa. A razão faz o endosso do contrato social. Olhemos agora algumas passagens das suas Reflexões, cursos e rascunhos para a Doutrina do Direito a fim de compreender a relação entre razão e vontade em relação ao contrato social e a punição.

O primeiro lugar a se olhar é em Naturrecht Feyerabend. A passagem que citei acima continua com a resposta de Kant a Beccaria:

Mas um ser humano não precisa assentir a punição, ele não disse: Eu quero muito ser punido. Ele assente apenas à lei penal e ele pensa que pode se safar dela. ${ }^{27}$

O assentimento à lei penal mencionada aqui é similar a asserção na Doutrina do Direito de que eu sou "um colegislador que dita a lei penal", com a diferença de que Kant usa a palavra "assentimento", o que faz do endosso do sistema uma questão relaciona-

27. Kant, I. Kants Gesammelte Schriften. Herausgegeben von der Königlich Preussischen Akademie der Wissenschaft. Vol. 27, pp. 1391 
da à vontade. Kant deve também ter em mente a vontade voluntária na frase "Eu desejo sofrer a punição". Há uma diferença entre assentir à lei penal pela vontade voluntária e o assentimento não voluntário ao contrato social pelo mesmo tipo de vontade que é equacionada com a razão. Mas como Kant faz esta distinção?

Uma passagem dos rascunhos de Kant para a Doutrina do Direito faz esta distinção em termos de vontade geral como oposto a vontade particular:

Justiça penal: a vontade de todos não pode impor uma punição a um indivíduo já que outros que não o indivíduo (que nunca concorda com sua pena) não constituem todos; do contrário, a vontade geral que é abstraída de cada indivíduo [pode impor a punição], isto é, a lei sob a qual cada indivíduo se coloca. ${ }^{28}$

$\mathrm{Na}$ Doutrina do Direito que foi publicada Kant não invoca a vontade geral nas suas passagens sobre punição. Nesta passagem, a vontade geral é invocada como a fonte de autorização para punir, em contraste com a vontade voluntária. A vontade geral é abstraída da vontade particular de cada pessoa. Dada a abstração, cada pessoa está em posição de colocar-se a si mesma sob a lei, isto é, de endossar as leis. O que precisamente é abstraído?

Mais a frente, nos rascunhos da Doutrina do Direito, em meio a mais discussão sobre a punição, Kant invoca novamente a vontade geral de um modo que pode ajudar a responder a questão:

A vontade geral do povo não é a vontade de todos sobre um caso dado, mas antes, aquela que meramente conecta estas várias vontades, isto é, a vontade comum que decide por todos é, pois, a mera idéia de unidade civil. 23:335

A vontade geral é entendida como sendo a idéia da unidade civil, não uma reunião de vontades voluntárias particulares. Aqui, a "vontade de todos" é tratada como um conjunto de vontades voluntárias. É dito desta vontade geral que ela "conecta" ou "une" (verknüpft) as vontades particulares. Isto parece indicar que o que

28. Kant, I. Kants Gesammelte Schriften. Herausgegeben von der Königlich Preussischen Akademie der Wissenschaft. Vol. 23, pp. 330. 
é abstraído é algo relacionado a particularidade da perspectiva individual.

Observando-se as reflexões, outra nota sobre Beccaria também nos dá uma indicação que o que é abstraído é algo relacionado com individuos particulares:

O cidadão não cedeu ao soberano, como acredita Beccaria, o direito sobre sua vida, nem fez um contrato ilegal e nulo, no qual o soberano não possa dispor sobre sua vida; pelo contrário, não depende de modo algum da preferência de cada um, se ele quer ser punido, antes, ele perde o statum civilem [estado civil] e é um fora da lei. ${ }^{29}$

O termo chave nesta reflexão é "preferências" (Belieben). E ela aparece novamente em outra reflexão:

Se uma sociedade se reúne em vista de um fim preferido, então ela não pode se obrigar à pena de morte. Mas, se ela se reúne em vista do fim de fundar uma sociedade civil, o que é necessário mediante a natureza, é necessária a obrigação de todos, entre outras penas, também à pena de morte. ${ }^{30}$

Aqui, a "preferência" está relacionada com um fim ou propósito para a formação da união civil. Nesta duas reflexões Kant está argumentando que um contrato social não pode ser baseado em preferências individuais. As preferências individuais, eu suponho, são desejos individuais e esperanças individuais de felicidade. É claro que indivíduos irão preferir permanecer vivos e fora da prisão, portanto, prefeririam evitar punições. Kant está observando que estas preferências não podem ser a base de um contrato social, pois, se o fossem, ninguém concordaria em permitir punições, em especial a pena capital. Logo, o que indivíduos devem abstrair ao assumir a perspectiva da razão são suas preferências particulares, isto é, seus objetivos particulares de felicidade.

Agora somos capazes de juntar estes fios de pensamento e ver como eles iluminam o argumento que Kant sustenta contra

29. Kant, I. Kants Gesammelte Schriften. Herausgegeben von der Königlich Preussischen Akademie der Wissenschaft. Vol. 19, pp. 551-2.

30. Kant, I. Kants Gesammelte Schriften. Herausgegeben von der Königlich Preussischen Akademie der Wissenschaft. Vol. 19, pp. 558. 
Beccaria na versão publicada da Doutrina do Direito. Naquela descrição Kant argumentou que a justificação da pena capital vem da razão mais do que da vontade voluntária. Como pode se dar isto, que o contrato social possa ser entendido como sendo independente de qualquer necessidade de endosso pela vontade voluntária? A resposta é que o contrato social não está baseado na felicidade, mas, do contrário, apenas na liberdade. Fosse o contrato social baseado na luta dos indivíduos pela felicidade, então eles teriam que avaliar a relação específica das leis e dos atos individuais do Estado em relação as suas próprias preferências e desejos. É por isto que punições severas como a pena de morte não seriam endossadas sob tal contrato social. Entrar ou não num contrato social seria uma questão de calcular a preferência de cada um e determinar se a felicidade esperada seria maior em um estado civil ou em um estado de natureza.

Contudo, o contrato social não é baseado em expectativas de felicidade. Para Kant, o contrato social é uma questão de direito, determinado antes e independentemente de qualquer preferência individual. Em suas obras publicadas, ele raramente se refere ao contrato social deste modo. O mais próximo a que ele chega é em Teoria e Prática, quando ele assevera que o direito, enquanto base do Estado, deve ser independente da felicidade. ${ }^{31}$ Entretanto, neste caso, seu argumento principal não está relacionado com as consequências desta visão para a coerência do contrato social, antes, é baseado na natureza do direito como a priori. Uma vez que questões do direito são a priori, ele afirma que questões empíricas tais como fins particulares ou concepções de felicidade não podem desempenhar nenhum papel na determinação do direito.

A discussão da relação entre punição e o contrato social, entretanto, iluminou outro aspecto desta separação entre direito e felicidade. Os efeitos desta concepção de contrato social são mostrados em detalhe nos argumentos de Kant sobre a punição. Somente uma concepção de contrato social que é baseada na abstração das preferências individuais, mesmo abstraindo da preferência geral

31. Kant, I. Teoria e prática. In:____Kants Gesammelte Schriften. Herausgegeben von der Königlich Preussischen Akademie der Wissenschaft. Vol. 8, pp. 289-90. 
pela felicidade, é coerente com a instituição da punição. Pois, se um contrato social fosse baseado em preferências e felicidade, Beccaria estaria correto em dizer que não se concordaria com a pena capital enquanto parte do contrato social. Este é o ponto ao qual Kant está se referindo na Reflexão 8037 citada acima.

Portanto, o contrato social não pode ser baseado na felicidade ou outros tipos de preferências. A vontade que endossa o contrato social deve ser abstraída daquelas preferências. A vontade geral faz exatamente isto. Nós vimos que a vontade geral é tal que difere de qualquer vontade particular e também difere do conjunto das vontades particulares (a vontade de todos). A vontade geral é, para Kant, a razão prática ela mesma. Enquanto razão prática, a vontade geral é a base para o consentimento individual ao contrato social. E a vontade geral, como sustentou Kant, insiste na instituição da punição como necessária para a existência do Estado.

Nas preleções Feyerabend, Kant sumariza de modo eloquente a relação entre felicidade, justiça e o propósito do Estado:

O bem-estar da república [Salus reipublicae] não consiste no conforto de cada indivíduo [Individui], porque o estado de natureza não é um estado de desconforto, mas de injustiça. Em consequência, a condição civil [status civilis] deve ser um estado que deve prevenir a injustiça. A condição republicana [Status reipublicae], é, portanto, liberdade, e sem dúvida como liberdade pública, e isto deve ser a meta do soberano supremo [imperantis summi]. Cada um deve ser tão feliz quanto possível: mas o dever do soberano \{imperantis\} deve ser o de estabelecer a justiça pública. ${ }^{32}$

A natureza do contrato social de Kant é iluminada por esta discussão. Para Kant, o contrato social se origina da razão pura prática, não de algum acordo contingente entre vontades voluntárias. É enganoso pensar que, para Kant, os acordos particulares em um contrato social são opcionais e dependentes de vontades voluntárias particulares. Eles são, antes, o produto da razão pura como expressado através da vontade geral.

32. Kant, I. Kants Gesammelte Schriften. Herausgegeben von der Königlich Preussischen Akademie der Wissenschaft. Vol. 27, pp. 1383. 
Como se mostrou no exemplo da punição e do contrato social, as fontes inéditas da filosofia política de Kant fornecem outra perspectiva sobre as obras publicadas. Nelas, o argumento contra Beccaria se insere num contexto mais amplo e recebe um tratamento mais aprofundado do que resulta se tomarmos apenas a Doutrina do Direito. Minerar esta fonte pode ser muito recompensador e valioso, e dos minérios das idéias brutas de Kant pode advir algum polimento para as barras de ouro das suas famosas obras. ${ }^{33}$

Tradução de Cauê Cardoso Polla

\section{Bibliografia}

ACHENVALL, G.; PÜTTER, S. Elementa Juris Naturae, Gottingen, 1750.

Jus Naturae. 5a. edição. Gottingen, 1763.

.; PÜTTER, S. Anfangsgründe des Naturrechts, Trad. por Jan Schröder, Frankfurt: Insel Verlag, 1995

ARNOLDT, E. Gesammelte Schriften. Band V, Teil II. Berlin: Verlag Bruno Cassirer, 1909.

BECCARIA, C. On Crimes and Punishments and Other Writings. Ed.

Richard Bellamy. Trad. de Richard Davies, Virginia Cox e Richard Bellamy. New York: Cambridge University Press, 1995.

Dos delitos e das penas. $3^{\mathrm{a}}$ ed. Trad. Lucia Guidicini e Alessandro Berti Contessa. São Paulo: Martins Fontes, 2005.

FLEISCHACKER, S. "Kant's Theory of Punishment". In: Williams, H. L. Essays on Kant's Political Philosophy. Chicago: University of Chicago Press, 1992.

KANT, I. Gesammelte Schriften. 29 Vols. Berlin: Walter de Gruyter, 1902 e ss.

- Metafísica dos costumes. In: Kants gesammelte Schriften. Herausgegeben von der Königlich Preussischen Akademie der Wissenschaft. Vol. 6. Berlin: Walter de Gruyter, 1902 e ss.

33. Este trabalho foi apresentado na Universidade de São Paulo em Agosto de 2009. Gostaria de agradecer ao professor Ricardo Terra e seus alunos pela discussão extremamente proveitosa sobre estes tópicos durante minha visita. 
Teoriaeprática.In:_____Kants Gesammelte Schriften. Herausgegeben von der Königlich Preussischen Akademie der Wissenschaft. Vol. 8. Berlin: Walter de Gruyter, 1902 e ss.

. Practical Pbilosophy. Trad. de Mary Gregor. New York: Cambridge University Press, 1996.

MALTER, R (ed.). Immanuel Kant in Rede und Gespräch. Hamburg: Felix Meiner, 1990, p. 217.

STARK, W. Nachforschungen zu Briefen und Handschriften Immanuel Kants. Berlin: Akademie Verlag, 1993. 